\title{
An Evaluation of the Rapid Antimicrobial Susceptibility Test by VITEK MS and VITEK 2 Systems in Blood Culture
}

\author{
Kang-Gyun Park ${ }^{1,2}$, Young-Bin $\mathrm{Yu}^{2}$, Keundol Yook ${ }^{3}$, Sang-Ha Kim ${ }^{4}$, Sunghyun Kim ${ }^{5}$, Young Kwon Kim ${ }^{2}$ \\ ${ }^{1}$ Department of Laboratory Medicine, Seoul St. Mary's Hospital, The Catholic University of Korea, Seoul, Korea \\ ${ }^{2}$ Department of Biomedical Laboratory Science, College of Medical Sciences, Konyang University, Daejeon, Korea \\ ${ }^{3}$ Department of Clinical Laboratory Science, Daejeon Health College, Daejeon, Korea \\ ${ }^{4}$ Department of Laboratory Medicine, Konyang University Hospital, Daejeon, Korea \\ ${ }^{5}$ Department of Clinical Laboratory Science, College of Health Sciences, Catholic University of Pusan, Busan, Korea
}

\section{혈액배양에서 VITEK MS와 VITEK 2 System을 이용한 신속 항생제 감수성 시험의 유용성 평가}

\author{
박강균 ${ }^{1,2}$, 유영빈 ${ }^{2}$, 육근돌 ${ }^{3}$, 김상하 ${ }^{4}$, 김성현 ${ }^{5}$, 김영권 ${ }^{2}$ \\ ${ }^{1}$ 가톨릭대학교 서울성모병원 진단검사의학과, ${ }^{2}$ 건양대학교 의과학대학 임상병리학과, ${ }^{3}$ 대전보건대학교 임상병리과, ${ }^{4}$ 건양대학교병원 진단검사의학과, \\ 5 부산가톨릭대학교 보건과학대학 임상병리학과
}

\begin{abstract}
The results of rapid antimicrobial susceptibility test (AST) in blood cultures were obtained by inoculating the bacteria directly into the VITEK MS and the VITEK 2 systems without subculturing in the blood culture positive medium. The obtained results were compared with the results using a standard method to evaluate their reliability and accuracy. The direct AST results in blood culture positive specimens were $97.9 \%(1,936 / 1,978)$, consistent with the standard AST results. Gram-positive bacteria showed a concordance rate of $97.2 \%(1,051 / 1,081)$, a very major error rate of $0.5 \%(5 / 1,081)$, a major error rate of $0.1 \%(1 / 1,081)$, and a minor error rate of $2.2 \%(24 / 1,081)$. Staphylococcus epidermidis was the main cause of discordance, and gentamicin $(\mathrm{N}=9)$ and fusidic acid $(\mathrm{N}=8)$ showed high errors. The overall concordance rate and minor error among the Gram-negative bacteria were 98.6\% (885/897) and 1.4\% (12/897), respectively. Escherichia coli and Pseudomonas aeruginosa were the major causative bacteria of Gram-negative bacteria. Among them, amoxicillin/clavulanic acid ( $N=3$ ) showed high error. Direct AST met the CLSI criteria and shortened the reporting time by 24 hours; however, we found that there was a need to perform an addition test via disk diffusion for antimicrobials with very large errors. These results suggest that the method of direct AST in blood culture positive medium may be very useful in efficiently treating patients.
\end{abstract}

Key words: VITEK MS system, VITEK 2 system, Blood culture, Rapid antimicrobial susceptibility test, Bloodstream infection

\footnotetext{
This is an Open Access article distributed under the terms of the Creative Commons Attribution Non-Commercial License (http://creativecommons.org/licenses/by-nc/4.0) which permits unrestricted non-commercial use, distribution, and reproduction in any medium, provided the original work is properly cited.
}

Copyright (C) 2017 The Korean Society for Clinical Laboratory Science. All rights reserved.

Corresponding author: Young Kwon Kim Department Biomedical Laboratory Science, College of Medical Sciences, Konyang University, 158 Gwanjeodong-ro, Seo-gu, Daejeon 35365, Korea Tel: 82-42-660-6371 Fax: 82-42-543-6370 E-mail: ykkim3245@konyang.ac.kr

Received: August 23, 2017 Revised: August 28, 2017 Accepted: August 28, 2017

\section{서 론}

패혈증은 혈류에 미생물이 감염되어 심각한 전신반응을 유
발하고 사망률이 높은 질환이며, 환자에게 경제적 부담 또한 증 가시키게 된다[1]. 최근 국내에서 이루어진 다기관 연구에서도 중증 패혈증에 의한 원내 사망률은 $34.3 \%$, 중환자실 내 사망률 
은 $29.1 \%$ 로 발표되었다[2].

자동화된 혈액배양 시스템을 사용하여 혈액배양 양성 미생 물을 고체배지에 계대배양 하여 집락이 형성될 때가지 일반적 으로 최소 12 시간에서 최대 48시간이 소요된다[3,4]. 고체배지 에서 증식된 집락을 채취하여 자동화 동정 장비에서 24 시간 검 사하면 세균 동정과 항생제 감수성 시험(antimicrobial susceptibility test, AST) 결과가 보고되지만 최종 보고까지 48시 간에서 72 시간이 소요된다.

혈류 감염을 일으키는 미생물의 신속한 동정 및 AST는 임상 에서 항생제를 선택하는데 있어서 중요한 역할을 한다[5]. 혈류 감염의 원인 세균을 동정하고 AST 시간의 단축은 경험적인 광 범위 항균제를 투여하는 대신 효율적이고 적절한 항생제를 투 여할 수 있고, 이는 환자의 임상증상의 회복을 향상시키는데 매 우 중요하다[6].

최근 matrix-assisted laser desorption ionization-time of flight mass spectrometry (MALDI- TOF MS)가 다양한 미생 물의 동정을 위해 임상미생물학 검사실에 도입 되었는데, 이 장 비는 몇 분 안에 세균과 효모를 동정할 수 있지만, 검사를 수행하 기 위해서는 18 48시간 배양된 독립된 집락이 필요하다[7]. 또 한, 세균동정과 AST에 소요되는 시간을 줄이기 위해 일부 연구 자들은 계대배양을 추가로 수행하지 않고, 혈액배양 양성 배지 에서 MALDI-TOF MS 시스템으로 직접 미생물을 동정하려는 시도들이 이어지고 있다[3,5-14]. 하지만, 혈액배양 양성 시료 에서 직접 세균을 동정하고 $\mathrm{AST}$ 를 수행하기 위해서는 시료의 준비단계가 필요하다. 혈액배양 배지에는 사람의 혈액 및 배양 액에서 파생된 단백질과 같은 잔해물들이 포함되어있기 때문에 MALDI-TOF MS 시스템으로 세균 동정 시 미생물의 스펙트럼 을 간섭할 수 있다. 따라서, 혈구 용해액인 염화암모늄, 에탄올, 포름산, 아세토 니트릴, 트리 플루오로 아세트산 등이 추가적으 로 사용되고 있다[5,6,11,13,14]. 또한, 용해 여과법[3,10], 겔 분리법[7], 시판용 검사 키트[8]를 시료 준비단계에 사용하기도 한다. 그러나, 이러한 시료준비 단계 중 일부는 과정이 복잡하 고, 시간이 많이 소요되며, 가격이 비싸기 때문에 경제적이지 못 하다[13]. 또한 아세토니트릴(acetonitrile)의 경우, 아세토니 트릴의 강한 냄새 때문에 시료를 준비하고 시약을 조작하는 과 정에서 흠 후드를 사용해야 하는 번거로움이 있다.

일부 연구에서 혈액배양 양성 검체의 직접 $\mathrm{AST}$ 수행을 시도 한 바 있다[3,6,9]. 그 결과, 직접법으로 MALDI-TOF MS와 VITEK 2 시스템을 병행할 경우, 표준방법보다 최대 24시간 빠 른 결과를 보고할 수 있다는 연구결과를 얻을 수 있었고, 이를 통 해 혈액배양 배지로부터 병원균의 직접 동정뿐만 아니라 AST도
유효성이 있음을 보고하였다[3]. 하지만, 이러한 방법들은 에탄 올, 포름산, 아세토 니트릴[6], 노동 집약적 용해 여과법[3]을 사 용하거나 그람음성 막대균 만을 대상으로 평가하였다[9].

따라서 본 연구에서는 이러한 제한점들을 보완하기 위해 질 량분석기와 AST 자동화장비를 이용해 혈액배양 양성 배지에서 계대배양 없이 세균 동정과 $\mathrm{AST}$ 를 동시에 시행하였고, 이러한 방법이 기존의 표준방법과 비교했을 때, 보다 신속하고 간단한 검사를 통해 신뢰성 있는 결과를 도출해 낼 수 있는지 신속 AST 의 신뢰도과 정확도를 평가해 보고자 하였다.

\section{재료 및 방법}

서울 소재 1,300 병상 규모의 상급 의료기관에 입원한 환자의 혈액배양 검체 중 양성으로 확인된 254개의 검체를 대상으로 연구를 수행 하였다. 혈액배양 양성시료를 계대배양 없이 기존 의 표준방법과 신속 AST 방법을 병행하여 수행하여 그 결과를 비교하였다.

\section{1. 추출 용해액의 제조}

추출 용해액 제조를 위해 9.26\% 염화암모늄(ammonium chloride) 용액(0.1 mL)과 $2 \%$ 사포닌(saponin) 용액을 혼합하 였다.

\section{2. 표준방법을 이용한 항생제 감수성 시험}

혈액을 채취하여 혈액배양용 배지인 산소성 배양 배지(Plus aerobic/F), 무산소성 배양 배지(Lytic/10 Anaerobic/F), 소아 용 배양 배지(Peds Plus/F) (Becton Dickinson, Franklin Lakes, $\mathrm{NJ}$, USA)에 접종하여 혈액배양 자동화 시스템인 BACTEC FX (Becton Dickinson)에서 배양 하였다. 혈액배양 양성 시 시료 는 sheep blood agar (Asan BAP I; Asan Pharmaceutical, Seoul, Korea)와 MacConkey agar (Asan Mac II; Asan Pharmaceutical)에 각각 $100 \mu \mathrm{L}$ 씩 접종하여 계대배양 하였다. Sheep blood agar는 $37^{\circ} \mathrm{C}, 5 \% \mathrm{CO}_{2}$, 암실 환경에서 24 시간 배 양하였고, MacConkey agar는 $37^{\circ} \mathrm{C}$, 암실 환경에서 24 시간 배 양하였다. 무산소성 배양은 sheep blood agar에 $100 \mu \mathrm{L}$ 를 접 종하여 $37^{\circ} \mathrm{C}$ 무산소성 환경에서 48 시간 배양하였다. 배양 후 고형배지에 형성된 세균 집락들은 AST용 VITEK 2 AST-N225 (bioMerieux)카드 Enterococci, Staphylococci, Streptococci, Enterobacteriaceae, Non-fermentative Gram-negative bacteria (NFB)에 접종하여 AST를 시행하였다. 최소 발육억제 농 도(MIC) 결과 값은 CLSI 지침에 따라 감수성(susceptible), 중 
등도도 내성(intermediate) 또는 내성(resistant)의 임상 범주 로 분류하였다[15].

\section{3. 혈액배양에서 직접법을 이용한 항생제 감수성 시험}

VITEK 2 시스템에 의해 총 120 개의 임상분리균주(그람양성 알균 69주, 그람음성 막대균 51주)는 동정에 따른 AST 카드 패 널로 분석을 수행하였다. 무산소성배지의 경우, 혈액배양양성 배지에서 $10 \mathrm{~mL}$ 를 채취하여 $15 \mathrm{~mL}$ 용량의 시험관에 넣고 $4,500 \times \mathrm{g}$ 에서 3 분간 원심분리하고, 상층액을 버리고 남아있 는 침사에 $0.45 \% \mathrm{NaCl}$ 로 2 회 세척하고, 마지막으로 $0.45 \%$ $\mathrm{NaCl} 10 \mathrm{~mL}$ 에 현탁시켜 나일론 메쉬 $(66 \mu \mathrm{m})$ 로 세포 파편을 제 거하였다. 필터 처리한 현탁액은 $4,500 \times \mathrm{g}$ 에서 3 분간 원심 분 리하고 침사는 $0.45 \% \mathrm{NaCl}$ 에 재부유하였다. 재부유한 현탁액 은 CLSI 지침에 따라 McFarland (McF) 0.5농도로 맞추어 VITEK 2 시스템을 사용하여 AST를 실시하였다. 스펙트럼 분석 을 위해 VITEK MS IVD system을 사용하였고, 검사결과는 제 조자가 제공 한 라이브러리 v2.0과 비교하여 분석하였다. VITEK MS에서 표적 슬라이드의 결과 값이 $90 \%$ 이상의 신뢰 수 준을 보였을 경우에만 유효한 결과로 사용하였다.

\section{4. 통계 분석}

직접법과 표준방법의 AST 수행 결과 비교는 CLSI에서 사용
하고 있는 용어인 매우 중대한 오류(very major error: false susceptibility), 대오류(major error: false resistance), 소오류 (minor error: susceptible/resistance versus intermediate susceptibility)로 평가하였다. 혈액배양 배지에 따른 평가는 산소성/무산소성 병의 성능을 통계적으로 비교하기 위해 Chi-square test 또는 Fisher's exact test를 사용하였다.

\section{결 과}

\section{1. 혈액배양에서 직접법과 표준방법에 의한 항생제 감수성 시험 결과 비교}

직접법을 이용한 AST 검사의 결과와 표준방법을 이용한 AST 결과를 비교하였을 때, $97.9 \%(1,936 / 1,978)$ 의 일치율을 보였 다. 매우 중대한 오류(very major error), 중대한 오류(major error), 사소한 오류의 비율(minor error)은 각각 $0.25 \%(5 / 1,978)$, $0.05 \%$ (1/1,978), 1.8\% (36/1,978)를 나타냈다(Table 1).

\section{2. 직접법과 표준방법에 의한 항생제 감수성 시험 간 불일치 결과 분석}

혈액배양에서 직접법과 표준방법에 의한 AST 결과를 분석하 였을 때, 그람양성 세균에서는 $97.2 \%(1,051 / 1,081)$ 의 일치율 을 보였고, 매우 중대한 오차율은 0.5\% (5/1081), 중대한 오차

Table 1. Comparison of results between direct and standard antimicrobial susceptibility test in blood culture

\begin{tabular}{|c|c|c|c|c|c|}
\hline \multirow{2}{*}{ Microorganisms } & \multicolumn{5}{|c|}{ Antimicrobial susceptibility test } \\
\hline & No. of test & Agreement & Minor error & Major error & Very major error \\
\hline Gram-positives & $1,081(100 \%)$ & $1,051(97.2 \%)$ & $24(2.2 \%)$ & $1(0.1 \%)$ & $5(0.5 \%)$ \\
\hline Staphylococcus aureus & 357 & 354 & 1 & 0 & 2 \\
\hline Staphylococcus epidermidis & 289 & 272 & 15 & 0 & 2 \\
\hline Staphylococcus haemolyticus & 34 & 32 & 2 & 0 & 0 \\
\hline Staphylococcus capitis & 136 & 133 & 2 & 0 & 1 \\
\hline Staphylococcus hominis & 34 & 33 & 1 & 0 & 0 \\
\hline Staphylococcus saprophyticus & 17 & 17 & 0 & 0 & 0 \\
\hline Enterococcus faecium & 144 & 143 & 1 & 0 & 0 \\
\hline Enterococcus faecalis & 60 & 57 & 2 & 1 & 0 \\
\hline Streptococcus pneumoniae & 10 & 10 & 0 & 0 & 0 \\
\hline Gram-negatives & $897(100 \%)$ & $885(98.6 \%)$ & $12(1.4 \%)$ & $0(0 \%)$ & $0(0 \%)$ \\
\hline Escherichia coli & 522 & 518 & 4 & 0 & 0 \\
\hline Klebsiella pneumoniae & 162 & 160 & 2 & 0 & 0 \\
\hline Enterobacter cloacae & 18 & 18 & 0 & 0 & 0 \\
\hline Enterobacter aerogenes & 36 & 36 & 0 & 0 & 0 \\
\hline Klebsiella oxytoca & 36 & 36 & 0 & 0 & 0 \\
\hline Serratia marcescens & 18 & 17 & 1 & 0 & 0 \\
\hline Providencia stuartii & 17 & 15 & 2 & 0 & 0 \\
\hline Pseudomonas aeruginosa & 56 & 53 & 3 & 0 & 0 \\
\hline Acinetobacter baumannii & 32 & 32 & 0 & 0 & 0 \\
\hline Total & $1,978(100 \%)$ & $1,936(97.9 \%)$ & $36(1.8 \%)$ & 1 (0.05\%) & $5(0.25 \%)$ \\
\hline
\end{tabular}


Table 2. List of cases that have discordant results in between direct and standard antimicrobial susceptibility test

\begin{tabular}{|c|c|c|c|}
\hline \multirow{2}{*}{ Microorganisms } & \multicolumn{3}{|c|}{ Antimicrobials (No. of cases) } \\
\hline & Minor error & Major error & Very major error \\
\hline Staphylococcus aureus & Erythromycin (1) & - & Gentamicin (2) \\
\hline Staphylococcus epidermidis & $\begin{array}{l}\text { Fusidic acid (7), Gentamicin (4), } \\
\text { Ciprofloxacin (2), Teicoplanin (2) }\end{array}$ & - & Trimethoprim/Sulfamethoxazole (2) \\
\hline Staphylococcus haemolyticus & Ciprofloxacin (1), Erythromycin (1) & - & - \\
\hline Staphylococcus capitis & Gentamicin (1), Fusidic acid (1) & - & Gentamicin (1) \\
\hline Staphylococcus hominis & Gentamicin (1) & - & - \\
\hline Enterococcus faecium & Ampicillin/ Sulbactam (1) & - & - \\
\hline Enterococcus faecalis & Erythromycin (2) & Erythromycin (1) & - \\
\hline Escherichia coli & $\begin{array}{l}\text { Amoxicillin/Clavulanic acid (2), } \\
\text { Piperacillin/Tazobactam (1), Cefepime (1) }\end{array}$ & - & - \\
\hline Klebsiella pneumoniae & Amoxicillin/Clavulanic acid (1), Ertapenem (1) & - & - \\
\hline Serratia marcescens & Tigecycline (1) & - & - \\
\hline Providencia stuartii & Piperacillin/Tazobactam (1), Imipenem (1) & - & - \\
\hline Pseudomonas aeruginosa & Amikacin (1), Cefepime (1), Aztreonam (1) & - & - \\
\hline Total & 36 & 1 & 5 \\
\hline
\end{tabular}

율은 $0.1 \%(1 / 1,081)$, 사소한 오차율은 $2.2 \%(24 / 1,081)$ 의 결 과를 나타냈다. 두 방법 간 불일치를 야기한 주요 원인균은 Staphylococcus epidermidis였고, 그 중 gentamicin ( $\mathrm{N}=9)$ 과 fusidic acid $(\mathrm{N}=8)$ 에서 높은 오류를 나타냈다. 그람음성 세균 중 두 방법에 의한 $\mathrm{AST}$ 결과의 전체적인 일치율은 $98.6 \%$ (885/897)였고, 사소한 오류는 1.4\% (12/897)였다. 그람음성 세균중 두 방법 간 불일치를 야기한 주요 원인균은 Escherichia coli와 Pseudomonas aeruginosa였으며, 그 중 amoxicillin/clavulanic acid (N=3)에서 높은 오류를 나타냄을 확인하였 다(Table 2).

\section{고 찰}

패혈증은 중환자실 내에서 높은 유병률뿐만 아니라, 중환자 실 내 사망의 주요 원인으로 알려져 있다[16]. 미국에서 중증 패 혈증은 인구 10 만 명당 300 례 정도 발생하였으며, 연령의 증가 에 따라 그 빈도가 증가하여 85 세 이상의 노인에서는 어린이에 비하여 약 100 배 이상 발생한다고 보고된 바 있다[17]. 최근 국 내에서 이루어진 다기관 연구에서도 중증 패혈증에 의한 원내 사망률은 $34.3 \%$, 중환자실 내 사망률은 $29.1 \%$ 로 발표하였다[2].

최근 몇 년 동안 유명인들이 패혈증으로 인한 급성심부전이 나 다발성 장기 부전 등으로 진행돼 사망에 이르게 되면서 패혈 증에 대한 사회적 관심이 높아졌지만, 뇌졸중이나 심근경색증 보다 사망률이 높음에도 여전히 인식부족으로 인해 폐렴 등 감 염병이 패혈증으로 악화하는 경우가 많았다. 이와 같이 패혈증 은 다양한 감염증이 동반될 수 있고, 여러 종류의 미생물 종이 원 인이 되기 때문에 그 원인체를 정확히 규명해내기 위해서는 혈
액배양이 필수적이다.

패혈증이나 균혈증 환자는 매우 위험한 상태이므로 혈액배 양을 통한 신속한 세균동정 결과는 환자의 치료에 매우 중요하 며 생존확률과도 밀접하게 연관되어 있다. 최근에는 신속하고 정확하게 병원체를 동정하기 위한 자동화 시스템이 도입되고 있다. 이에 본 연구에서는 혈액배양에서 신속한 세균 동정과 AST 결과를 얻기 위해 혈액배양 양성배지에서 계대배양 없이 세균을 VITEK MS와 Vitek 2 시스템에 직접 접종하였으며, 도 출된 결과를 표준방법과 비교하여 그 신뢰도와 정확도를 평가 하였다.

본 연구에서 AST의 정확도는 그람양성 세균과 그람음성 세 균 모두에서 우수하게 나타났으며, AST의 일치율은 다른 연구 들에 비해 우수하거나 유사한 수준으로 나타났다[3,6,9]. Machen 등이 보고한 연구에 의하면 그람음성 막대균 중 심각 한 오류의 원인이 되는 주요 세균은 Proteus spp.로 ampicillin, cefazolin, ceftazidime, ceftriaxone 등의 다양한 항생제에서 나타난다고 보고하였지만, 본 연구에서는 Proteus spp.가 포함 되지 않았다. 그람양성 세균은 $97.2 \%(1,051 / 1,081)$ 의 일치율 을 보였으며, 매우 중대한 오차율은 0.5\% (5/1081), 중대한 오 차율은 $0.1 \%(1 / 1,081)$, 사소한 오차율은 $2.2 \%(24 / 1,081)$ 의 결과를 나타냈다. 불일치의 주요 원인균은 S. epidermidis였으 며, 그 중 gentamicin (N=9)과 fusidic acid (N=8)에서 높은 오 류를 나타냈다. 그람음성 세균 중 전체적인 일치율은 $98.6 \%$ (885/897) 였고, 사소한 오류는 1.4\% (12/897)였다. 그람음성 세균의 불일치 주요 원인균은 E. coli와 P. aeruginosa였으며, 그 중 amoxicillin/clavulanic acid (N=3)에서 높은 오류를 나 타냈다. 그람양성 세균에서는 Staphylococcus spp.에서 매우 
중대한 오류가 발견되었으며, 관련 항생제는 gentamicin과 trimethoprim/sulfamethoxazole이었다. 이결과는 Machen [14] 등이 보고한 내용과 일치하였다.

향후 추가적인 연구에서는 본 연구에서 주된 오류의 원인이 되었던 streptococci와 coagulase negative staphylococci (CoNS)에 의한 중대한 오류의 원인 분석과 이를 개선하기 위한 노력이 필요할 것으로 사료된다. 본 연구에서 평가한 직접법에 의한 AST는 CLSI 기준을 충족하였고, 결과 보고 시간을 24 시간 단축할 수 있었지만, 매우 큰 오류가 있는 항균제에 대해서는 디 스크확산법으로 추가적인 검사를 시행할 필요성이 있다는 것을 알 수 있었다. 이러한 연구 결과들을 토대로 혈액 배양액에서 직 접 AST를 실시하는 방법은 90\% 이상의 높은 정확도를 가지고 결과 보고 시간을 크게 줄일 수 있기 때문에 환자의 신속하고 정 확한 치료에 매우 유용할 것으로 사료된다.

\section{요 약}

본 연구에서는 혈액배양에서 신속한 세균 동정과 항생제 감수 성 시험(antibiotic susceptibility test, AST) 결과를 얻기 위해 혈액배양 양성배지에서 계대배양 없이 세균을 VITEK MS와 VITEK 2 시스템에 직접 접종하였으며, 도출된 결과를 표준방법 과 비교하여, 그 신뢰도와 정확도를 평가하였다. 혈액배양 양성 시료에서 직접 결과는 표준방법 $\mathrm{AST}$ 결과와 비교하였을 때, 97.9\% (1,936/1,978)의 전체적인 일치율을 보였다. 그람양성 세 균은 $97.2 \%(1,051 / 1,081)$ 의 일치율을 나타냈으며, 매우 중대한 오차율은 0.5\% (5/1081), 중대한 오차율은 0.1\% (1/1,081), 사 소한 오차율은 $2.2 \%(24 / 1,081)$ 의 결과를 나타냈다. 두 방법 간 불일치의 주요 원인균은 Staphylococcus epidermidis이었고, 그 중 gentamicin (N=9)과 fusidic acid (N=8)에서 높은 오류를 나타냈다. 그람음성 세균 중 전체적인 일치율은 $98.6 \%$ (885/897)였고, 사소한 오류는 1.4\% (12/897)였다. 그람음성 세균의 불일치 주요 원인균은 Escherichia coli와 Pseudomonas aeruginosa였으며, 그 중 amoxicillin/clavulanic acid $(\mathrm{N}=3)$ 에서 높은 오류를 나타냈다. 직접법에 의한 $\mathrm{AST}$ 방법은 CLSI 기준을 충족하였고, 결과 보고 시간을 24 시간 단축할 수 있었지만, 매우 큰 오류가 있는 항생제에 대해서는 디스크확산 법으로 추가적인 검사를 시행한 후 보고해야 한다는 것을 알 수 있었다. 이러한 연구 결과들을 토대로 혈액배양 시료에서 직접 $\mathrm{AST}$ 를 실시하는 방법은 정확하고 결과를 보고하는데 까지 소요 되는 시간을 크게 감소시킬 수 있기 때문에 환자의 정확하고 효 율적인 치료에 유용하게 활용될 수 있을 것으로 사료된다.

\author{
Acknowledgements: None \\ Funding: None \\ Conflict of interest: None
}

\section{REFERENCES}

1. Watson RS, Carcillo JA, Linde-Zwirble WT, Clermont G, Lidicker J, Angus DC. The epidemiology of severe sepsis in children in the United Stated. Am J Respir Crit Care Med. 2003; 167(5):695-701.

2. Kim JH, Hong SK, Kim KC, Lee MG, Lee KM, Jung SS, Choi HS, Lee JH, Jung KS, Lee SS, Cho JH, Koh SO, Park MS, Seo KW, Koh Y. Influence of full-time intensivist and the nurse-to-patient ratio on the implementation of severe sepsis bundles in Korean intensive care units. J Crit Care. 2012;27:414.e11-21.

3. Machen A, Drake T, Wang YF. Same day identification and full panel antimicrobial susceptibility testing of bacteria from positive blood culture bottles made possible by a combined lysis-filtration method with MALDI-TOF VITEK mass spectrometry and the VITEK2 system. PLoS One. 2014;9:e87870.

4. Schneiderhan W, Grundt A, Wörner S, Findeisen P, Neumaier M. Work flow analysis of around-the-clock processing of blood culture samples and integrated MALDI-TOF mass spectrometry analysis for the diagnosis of bloodstream infections. Clin Chem. 2013;59(11):1649-1656.

5. Prod'hom G, Bizzini A, Durussel C, Bille J, Greub G. Matrix-assisted laser desorption ionization-time of flight mass spectrometry for direct bacterial identification from positive blood culture pellets. J Clin Microbiol. 2010;48(4):1481-1483.

6. Romero-Gómez MP, Gómez-Gil R, Paño-Pardo JR, Mingorance J. Identification and susceptibility testing of microorganism by direct inoculation from positive blood culture bottles by combining MALDI-TOF and Vitek-2 Compact is rapid and effective. J Infect. 2012;65(6):513-520.

7. Stevenson LG, Drake SK, Murray PR. Rapid identification of bacteria in positive blood culture broths by matrix-assisted laser desorption ionization-time of flight mass spectrometry. J Clin Microbiol. 2009;48(2):444-447.

8. Kok J, Thomas LC, Olma T, Chen SC, Iredell JR. Identification of bacteria in blood culture broths using matrix-assisted laser desorption-ionization Sepsityper $^{\mathrm{TM}}$ and time of flight mass spectrometry. PLoS One. 2011;6:e23285.

9. Ling TK, Liu ZK, Cheng AF. Evaluation of the VITEK 2 system for rapid direct identification and susceptibility testing of gram-negative bacilli from positive blood cultures. J Clin Microbiol. 2003;41(10):4705-4707.

10. Fothergill A, Kasinathan V, Hyman J, Walsh J, Drake T, Wang YF. Rapid identification of bacteria and yeasts from positive-blood-culture bottles by using a lysis-filtration method and matrix-assisted laser desorption ionization-time of flight mass spectrum analysis with the SARAMIS database. J Clin Microbiol. 2013;51(3):805-809.

11. Lavergne RA, Chauvin P, Valentin A, Fillaux J, Roques-Malecaze C, Arnaud S, et al. An extraction method of positive blood cul- 
tures for direct identification of Candida species by Vitek MS matrix-assisted laser desorption ionization time of flight mass spectrometry. Med Mycol. 2013;51(6):652-656.

12. Ferreira L, Sánchez-Juanes F, Porras-Guerra I, García-García MI, García-Sánchez JE, González-Buitrago JM, et al. Microorganisms direct identification from blood culture by matrix-assisted laser desorption/ionization time-of flight mass spectrometry. Clin Microbiol Infect. 2011;17(4): 546-551.

13. Monteiro J, Inoue FM, Lobo AP, Sugawara EK, Boaretti FM, Tufik S. Fast and reliable bacterial identification direct from positive blood culture using a new TFA sample preparation protocol and the Vitek $\mathrm{RMS}$ system. J Microibiol Methods. 2015;109:157-159.

14. Marinach-Patrice C, Fekkar A, Atanasova R, Gomes J, Djamdjian L, Brossas JY, et al. Rapid species diagnosis for in- vasive candidiasis using mass spectrometry. PLos One. 2010;5:e8862.

15. Clinical and Laboratory Standards Institute. Performance standards for antimicrobial susceptibility testing. 24th Informational supplement, M100-S24. Wayne, PA: Clinical and Laboratory Standards Institute; 2014.

16. Hong SK, Hong SB, Lim CM, Koh Y. The Characteristics and Prognostic Factors of Severe Sepsis in Patients Who Were Admitted to a Medical Intensive Care Unit of a Tertiary Hospital. Korean J Crit Care Med. 2009;24(1):28-32.

17. Angus DC, Linde-Zwirble WT, Lidicker J, Clermont G, Carcillo J, Pinsky MR. Epidemiology of severe sepsis in the United States: analysis of incidence, outcome, and associated costs of care. Crit Care Med. 2001;29(7):1303-1310. 